19

CXPANDED TECHNICAL ASTISTANCE PROARAM

\title{
Report
}

to the

\section{GOVERNMENT OF AFGHANISTAN}

on

\section{FARM IMPLEMEN'TS}

\section{AND SHALL POWERED MACHINES}
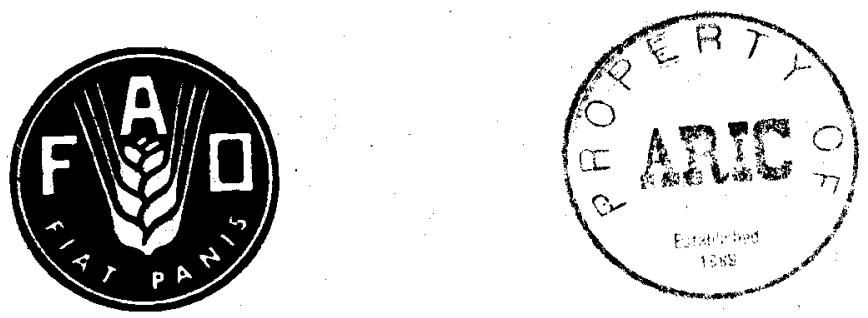

FOOI AND AGRICULTURE ORGANIZATION OF THE UNITED NATIONS ROME, 1958 


\author{
RPPOPT \\ to the \\ GOVERNIEITI OT AFGHAIISTII
}

on

FARA IMPLEUENTS AND S.ALI PONERED NACHINES

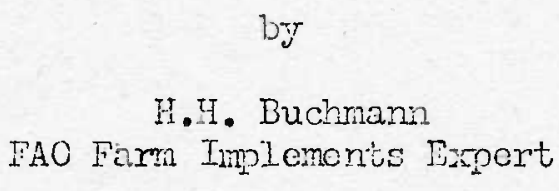

Rome, 1953 


\section{CONTENTS}

Page

INTRODUCTION ............................. 1

I. ACKNOWLTDGEMENTS $\ldots \ldots \ldots \ldots \ldots \ldots \ldots \ldots \ldots \ldots \ldots \ldots \ldots \ldots \ldots$

II. THE SITUATION ........................... 2

III. SUMMLRY OF RECOMLENDATIONS ................... 3

IV. THE PROGRAM AND PROGRESS OF WORK ............... 3

Background Information ................. 3

Improved Harvesting, Throshing and Winnowing ...... 5

Improved Tillage, Soeding and Intor-cultivation ... 7

Organizational Work ...................... 10

V. THE FUTURE DEVELOPMENT OF THE PROGRAI .............. 10

The Cotton Program ....................... 11

Establishmont of an Agricultural Engineering

Section within the Ministry of Agriculture ....... 15

FAO/50/4/2445 


\section{INTRODUCTION}

In accordance with Supplemental Agreements Nos. 5 and $5 \mathrm{E}$ between the Government of Afghanistan and the Food and Agriculture Organization of the United Nations, an expert on farm implements and small powered machinos was assigned to advise and assist the Government by means of the following measures:

1. tosing and adapting farm implements and machinory suited to the agricultural conditions of the countr: taking into account both economic and social considerations,

2. improving traditional implements produed in the country,

3. cemonstrating selocted egricultumal implcments and machinery and training local technicians in their use,

4. orgenizing the continuation of the project or a national basis.

The expert, Nr. H. H. Buchmann, was in Afghanistan Irom 20 July 1954 until 14 December 1957. His assignment was a follow-up to the one injerroce in 1951.*

\section{ACKNOWTIDDCENEIVTS}

The expert acknowledges with thanks the cooperition received from:

H. E. Mir Moharimed Yussuf - Minister or Agriculture

H. E. Ghulam Siddiq - Deputy MEnister of Agriculture

H. E. Ismail Khan

- former GovernormGeneral o: Kataghas

H. F." Juma Khan

- present Governor-Geneial of Kataghan

H. E. Farouk Than

- Governor-General of Fastern Province

* 1) W.Sommerauer: Small Agricultural aplonont - FAO Report No. 23 -

2)

II

$\therefore$

11

i! Apri1 1952

and Tarm Tools - FAO Report 10. 195, TTorember 1953

FAO $/ 58 / 4 / 2445$ 
Mr. Yasin Mail

Nr. Ghulam lvakshband

Mr. Abdul Rahim
- Director-General of Agronomy Ministry of Agriculture

- Director, Foreign Relations Department

-. Director, Ministry Farm at Kunduz

The Sugar Company in Baghlan,

and particularly his two counterpart officers, Mr. Hohamned Ali Akberzade and. Mr. Moharmed. Ishaq Rastagar, who, together with other technical and administrative personnel, sometimes under great difficulties and with personal sacrifices helped to corry out the project.

\section{THE SITUATION}

Afghanigtan's traditional agriculture provides the main souroe of income for the country. The financing of national development plans therefore depends to a lerge extent on how agricultural production can be increased. There is need ana scope for a rapid expansion of the main national cash products such as wheat, couton, sugar beet and karakul.

Quite obviously ary major increase in Afghan agricultural production can only be brought about by the great number of Afghan farmers, and consequently, any innovation should be of a nature affording real benefit to the average farmer.

Ls a result of long seclusion the Afghan farmer is still unfamiliar with the rapid technical development in other parts of the world, he has not yet acquired the mechanical skill and knowledge of modern farming methods, nor has he built up the financial resources to take advantage of specialized power machinery. The still difficult communications and the entire lack of service facilities do not favour the use of power machinery, but on the other hand, there is a large reserve of power in the fine horse population of northern Af ghanistan which has been insufficiently employed for field work. This power can to a large extent, be exploited with little additional cost, and it would centainly help to increase yields in the cash crop production. Improved animel-drawn equipment could be owned and handled by the average farmer with limited training and with guidance from the staff of the Winistry of Agricultixe. It would ke possiole to introduce such improvements on a broad scale within the foreseeable future. The introduction of power machinery would require a considerable amount of training and supervision, but its demand on finance and educated personnel, in spite of absorbing all available sacilities, "yould only cover co limited area. 
With the introduction of modern tillage and cultivation methods with up-to-date animal powered equipment at least half the way would be paved for the later introduction of power machinery. The result of this development would be the better knowledge, skill and financial resources of the farmers in readiness for the day when tractors move. in.

\section{SUMMARY OF RECOMENDATIONS}

The solution of the problems facing the country in the field of agriculture requires:-

1. That the available means and facilities be concentrated on:

(a) the improvement of implements and methods for rowcrop cultivation - cotton in the first instance;

(b) the promotion of implements and methods to accelerate the wheat harvest in order to free both the labour force and animal power for the timely cultivation of rowcrops;

(c) the production of a foddor supply for animals throughout the year, particularly for the karakul shoep in winter, with the aid of improved implements.

2. That an Agricultural Enginecring Scotion within the Ministry of Agriculturo be established for initiating, guiding and maintaining the technical development of that section of Afghan agriculture on a sound national basis.

\section{THE PROGRAM AND PROGRESS OF WORK}

\section{Background Information}

So far Afghan africulture has been bascd on cxtromely simple methods and imploments mainly powered by men and animals. The strongest draft power on the farm is a pair of light bullocks in a double yoke. In some aroas of the northern provinces light horses take the place of bullocks. The three Afghan implements, the plough (espar), the lovelling board (mahla) and the shovel harrow (rakel) are adaptod to theso sourcos of power. In addition the sizo of the fields is rolated to the draft capacity of tho animals. As far as is knows, no attompts havo beon mado to combino more than two animals 
in a span, nor is there any imploment roquiring more powor. All work has traditionally been divided into fractions which can be accomplished with existing power units. On the other hand, single animals are not yet used to perform light ficld work. With tho exception of the sugar beet arca, where carts drawn by one horse are used to a limited extent, all farm products are carried to and from the rields and also to tho market by donkeys, horses and camels. In some aroas of the northern provinces the wheat bundies are transportod to the throshing place by bullock-drawn sledges. Animals aro also used for threshing.

Tho opening of iraigation ditches, the ridging, all seeding, cultivating and harvesting, and the winnowing and cleaning of seeds are performed by hand. The denso population of the Eastern Province supplies abundant manpower and thoro is also a regular seasonal influx of semi-nomadic farmers and labourers into tho Kabul Province. The fields are well tended in these places and the only prossing problom seems to bo the noed for speeding up the harvesting, throshing and winnowing. In addition to reducing the grain lossos it would also free the bullocks for the early ploughing of stubble. Immediate ploughing of tho stubble aftor harvesting is not practised.

Tho wheat harvest in the Kabul Province starts in the second half of June. The fields are thon clearod up and roleasod for pasturing of animals, including chiokon. When water bocomos availablo for irrigation and the bullocks can be spared from throshing, the fields arc ploughed and then lie fallow for tho rost of tho yoar, except whero ryo or another winter wheat orop is som in octobor or November.

The power problem is far more serious in the agriculture of the northorn provinces of Afchanistan. Those aro sparsely populatod, whilst the cotton and sugax boot grown in adition to wheat domand more labour. Soasonal labour is scarce. Gencielly farming practices are the same as described for the Kabul Province, with tho exroption of a heavy chopping hoe (ketman) being used instcad of the woeding sickle (kala). In some places of the sugar beet area instoad of using the two-man shovel (palkash), furrows aro made with the local plough, to which wooden planks aro fixed, otherwise ridges are made with tho two-man shovol.

The netural conditions aro very favourable for cotton and sugar boot growing, but tho averago yield of both crops is loss than half of what it could be. This situation is mostly due to poor cultivation. It is ovident that in many cases either the power is insufficiont or it is inadequately utilized to porform the work in time. As a result, the planting on a substantial acroage is dolayod, and thinning and hoeing, if done at all, is equally too late. Miany crops got complotoly over-run by woeds during tho growing season. Thile tillago is performed with animal power, inter-cultivation depends entirely on manpower. The available farm hands, however, do not succoed in cultivatinô as much during tho growing season, as has boen

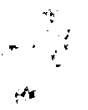


tilled with animal powcr bofore planting. In the opinion of the expert the main problom consists in inter-cultivation rather than in the preparation of the secabed.

\section{Improvod Harvesting, Throshing and Winnowing}

Improved Harvosting. As a first contribution towards tho solution of the above mentionod problom, the oxport assistod in establishing a program to speed up the harvosting of coroals, ospecially wheat, in Kataghan, with the objectivo of releasing labour and animal power for the inter-cultivation of cotton and sugar beot, and to improve throshing and winnowing. The followino activitios wore initiated:

(a) Cutting of fodder crops; such as clover and alfalfa, with the scythe in onc-fifth or less of the time required with the sickle.

(b) Reaping of barley, whoat and ryo with a scytio and cradle in one-third of tho time requirod with tho sickle.

(c). Throshing with. disc harrows or rollor throshers in one-third to onc-fifth of the timo required with the throshing slodge (djugol).

(a) Immodiato stubblo ploughine to proscrve the extra moiaturo requircd for tillago, aftor tho soil has become hard, and to grow an additional leguminous foddor crop in the remaining. soason.

(c) Sood cloaning with hand-oporatod Afghan mado sood cleanors.

The time gainod by the now harvesting and threshing practices pormitted tho winnowing. of all barley, ryo and whoat during the period of strong winds which prevail in Kabul until the second half of Soptember, and above ali the cultivation of moro land.

Thorough training, with subsequent guidanco, in harvesting with the scythe and cradle, rake and fork instoad of with the traditional sickle was given to profossional reapers exclusively until full appreciation of the benefits to be derived from the new mothod was achieved. The moro proficient. were promoted to the extent that they could act as instructors to thoir fellow-cultivators and tribesmen.

In 1955 a demonstration team composed of twelve such instructors under the direction of one of tho cxpert's cuuntorparts trained more than 600 farmers in the sugar beot area of Kataghan. 
In 1956 the instruction campaign was extended to the semi-nomadic cultivators who do most of the harvesting in the Kabul province. In spite of initial difficulties, good nuclei were established with two semi-nomadic tribes where some men achieved outstanding success with the new method and thus became exoellent propagandists on their subsequent migration. An oven better local result was aohieved with small farm owners in the villages of Chardi, south-west of Kabul. The best of the men more than trobled his daily earnings during harvost time and trained 40 fellow cultivators who bought their own scythe outfits. In addition, 28 village level workers of the Community. Devolopment. Project were trained on the. same lines as looal instruotors.

The instruction in the use of the scythe is making an increasingly significant contribution towards the devolopment of Afghanistan's agriculture. The costs of harvesting are reduced and at the same time tho reapors inorease their daily income. Considerable loss of grain can bo avoided by finishing the wheat harvest in good time. The easy cutting of forage crops with the scythe encourages. the farmors to increase their acreage, a basic feature for enriching the Afghan soils and obtaining highor crop yields, and an eminently basic feature for Afghanistan's broeding programs. The scythe enables sheep brceders in the Northern Stoppes to cut and dry the abundant grass of the steppes in spring for fodder during the seasons of shortage.

There is no durbt that the scythe will rapidly gain popularity. In addition to the scythe, the light animal-drawn mower with reaper attachment will prove to be of economical advantage in the larger fields of the north. Unfortunately, nono of the horse-drawn mowers owned by the Ministry of Agriculture is oquipped with a reaper dovice. These are essontial for the harvesting of wheat and other cercals and must cithor be imported or manufactured locally. Further tests with differont throshing and winnowing cquipment aro necossary to secure oconomic data and to arrive at conclusive results as to which mothod should be promotod in Afghanistan.

Improved Throshing. The question whethor the drum thresher would not be tho best solution is ofton raised. Its advantages over the traditional method would result in quickor and better throshing and winnowing. The grain is graded and many of the weed seeds are sifted out and can then be destroyed. The main disadvantage is that the straw is not bruised as required by the Afghan farmor as long as the animals are fod on straw. The drum threshor vould thorofore have to bo equipped with some additional device for bruising tho straw, which would incroase the power requirements as well as the cost.

The threshor should bo providod with an engine for operation and transport from place to place. A tractor and a powor-take-off operated throshor of medium or high capacity would tcchnically appear to provide the best solution and may also be the choapost in operation, but financial invostments are so high that thoir introduction on a large-scale is not economically fcasible for quito some time to come. 
Hand-operated threshers have been tested but cannot be recommended, because too much power is required. These were constructed of wood, which is subject to considerable warping in the dry climate of Afghanistan. For future trials only steel threshers ought to be considered.

Straw Bruising. It will be necessary to ascertain from trials whether the hand-operated chaff-cutter would provide a cheap substitute for the bruising of straw. This implement is very popular in many countries due to its advantage of preparing dry as well as green foddar. There are indications that straw in the dry climato of Afghanistan is too hard but, if it can be mixed with green stuff, this drawback may be overcome. There are areas in Afghanistan where green fodder can be grown all the year round.

Improvod Tillage, Seeding and Inter-cultivation

The labour and drait animals released after the wheat harvest should be usefully cmployed in the inter-cultivation of rowcrops. As the problem of the improvement of inter-cultivation is of basic importance for Afghanistan, it is dealt with in this report before tillage and seeding. A real solution to tho problems of inter-cultivation of cotton and sugar beet can be brought about if the scarce handpower in the northern areas is replaced by animal power. There is a considerable rescrve of animal power in the horse population of Kataghan and Mazir-i-Sharif which so far has hardly been used as draft animals for field work.

Inter-cultivation. Proposals for a campaign to introduce animal power in the inter-cultivation of cotton have been worked out. Succusaful field demonstrations were held in 1957 and the field officers of the Ministry of Agriculture in Kataghan were instructed, by means of a training course in different methods of planting and inter-cultivating cotton with combined hand-operated and animal-drawn equipment.

Similar mothods will also answer the requirements of sugar beet, but their introduction is more difficult because the farmers will have to abandon their present practices almost entirely in favour of the new methods. The results achieved in cotton growing should be noted.

The program for the mechanization of tho cotton production with a combination of animal and hand-operated implements will have great influence on the progress of Afghan farming beyond the immediate increase in crop yields. For the first time, in two provinces, implements will come to the farms cquippod with nuts and bolts and wrenches. This means that the farmers; and especially the younger generation., will have the opportunity to become familiar with the rudimencs of farm mochanization. Sufficient provision must be made for spare nuts and bolts and wrenches as a considerable number of thom will no doubt be danagod at first, but this type of basic selfeducation will be well worth the price.

FAO/58/4/2445 
The light hand-operated pulling hoes of Western dosign are more likoly to bo appreciatod by tho farmors, once they can bo used in conjunction with animal or tractor powered implomonts. For tho cultivation of cotton the flexiblo tino harrow, howevor, offors the possibility to further docroaso manual work. In Central Europe, potatoos aro grown with this implemont without any hand hooing at all. FAO has sont samplos to Afghanistan for demonstration and trials should be undortaken to detormine whethor this imploment can be uscd to roplace cultivation by hand in cotton production. This implement provides a solution to the serious problom of weed control in the wheat fields of Kataghan and it can also broak tho caking surfaoe of soils in young maizo fiolds.

The fine texture of the Afghan looss soil, togethor with the frequent irrigation, makes the aoration of the soil much more of a problem than is gonorally roalizod. Tho soil is not acratod as much with tho cultivatortype plough as with tho mouldboard plough. Where basin irrigation is practisod, the ontire surface is almost scaled by the wator. The Afghan farmor has found a way out by growing many of his crops on ridgos, the tops of which are not reached by tho irrigation water. Farmers should be advised not to abandon tho ridge systom in favour of growing crops on the flat unless they aro made familiar with efficiont moans of inter-cultivation. Whore cultivation on tho flat is now practised, a substantial incrcase in yiold may bo anticipatod if inter-cultivation is proporly ostablished.

For efficient inter-cultivation, crops like cotton, sugar boet and maize must bo grown in rows. While seedors may be rocommendod for sugar boot and maizo, the planting of cotton with machinos becomes a special problem, unless the seed is delintod or vory carofully ginned. Until suitable seed is available and tho farmers have acquirod more exporience with machinery it is proferable to plant cotton by hand to ensuro good stands in the ficlds.

In tho opinion of the expert, all efforts at this time should concentrate on the promotion of up-to-date inter-cultivation mothods. Only after these have been genorally adoptod, should renewed attention be given to the preparation of a bettor scodbed.

Primary Tillage. Much discussion has alroady boen devoted to the native plough and tillage requiroments undor climates similar to that of Afghanistan. Many ondeavours have boen made to roplace the scemingly primitive native plough by a bottor implemont. Undor this projoct many suggestions were put forward, but in practico it is difficult to supplant the Afghan plough by another cultivator-typo implement if the draft roquiremonts and woight are not to be incroased. The indigenous plough conforms to the limited power of a pair of bullocks and to the strength and skill of the ploughman. Its transportation to the field crcates no problem, and in spite of excessive time consumption in hoavy soils, it mocts tho roquiroments. Tests showed that its penetration of the soil at first ploughings was superior to all new versions of animal-drawn cultivatox-type ploughs. This was due to ita 
long bottom, which permits exceptionally good power utilization. Attempts to construct the same typo in iron tend towards a hoavier implement, and to the use of materials which are beyond the scope of the village blacksmith. The expert is of the opinion that the indigenous plough should not be undex estimated merely because wood is usod for its construction. Wood has qualities which are hard to equal.

The great disadvantage of the indigenous plough is that it does not out the whole ploughed area, and in its course often deviates round tough roots, leaving them intact. The following points might assist to ovoroome this drawback, but during the period of the assignmont it was not possible to put
them into practico:

(a) A special share could be used for the seoond and subsequent ploughings, on which the rims aro roinforcod and uxtondod. on both sjdos as far w tho normal dxceft powor convoniontly allows.

(b) The introduction of a bettor steel for the share on the native plough.

(c) The course of the plough must be stabilized to a straight line to prevent it from moving too easily sideways around obstacles. This may be achieved by inserting a ventral iron edge into the plough bottom which protmedes about 2 " from behind the iron share. The most suitable shape will hovo to be ascertainod from comporativo field tosts.

(d) More accurate work ought to be done by the ploughman. Apart from his skill and the training of animals, there is the question of improving the guidance given to the animals by means of better harness.

A modified three prong version of the Italian Giusti cultivator was also developed with the object of substituting the indigonous plough. The present type can well be used for the second and subsequent ploughings but the Afghan plough is superior for first ploughing.

Further improvements of this new implement are however being developed. Nevertheless it is not advisable to rocommend this or any other new implement to the farmer before it can completely replace the old plough.

Progress in improving the plough would result in a major contribution towards a better seedbed and more timely performance of field work. The performance of timely field work is probably the most important single factor for increasing the yields of Afghan crops. 


\section{Organizational Work}

The success of the project is to a large degree dependent on building up an organization which would assume responsibility for oontinous methodical work in this field. The expert submitted recommendations for tho establishment of an Agricultural Engineering Section within the framework of the Ministry of Agriculture which fully takes into account the present limitations imposed by the lack of qualified staff at the Ministry of Agriculture. With due regard to this basic factor, FAO granted a fellowship to an officer of the Ministry of Agriculture, who after completion of his studies, is now well qualified for leadership in this field.

\section{THE FUTURE DEVELOPMEIVT OF THE PROGRAM}

After exploring the various possibilities for a rapid increase of oash crops in Afghanistan, the expert reached the conclusion that the introduction of improved inter-cultivation methods in cotton with combined animal-drawn and hand-operated implements could be accomplished with the available facilities on such a broad scale that, within a few years, the Afghan cotton production would be increased by more than one-third of its present capacity. This achievement would be of high significance for the Afghan national economy and a milestone in the development of agricultural techniques in Afghanistan.

During the next years therefore all efforts of the Farm Implements Project should be concentrated on the realization of this program for cotton. At the same time this will cffer a fine opportunity for building up the services of the Ministry of Agriculture for expansion activities in later years. The program is based on three aspects:

(a) Proper inter-cultivation with animal-powered equipment, with the primary necessity of exploiting the as yet unemployed power of the horse population in the northern provinces of Afghanistan.

(b) Timely performance of the field work, the factor which definitely leads to both higher yields and reduced costs.

(c) Firm national guidance by appropriate sections of the Ministry of Agriculture.

These aspects all have to be given due considerationg failure in any one of their phases would immediately compromise the whole program. 


\section{The Cotton Program}

The following are proposals for the animal-powered mechanization of the cotton production in Northern Afghanistan:-

1. Experts agree that, based upon informal ficld observations in recent years, the cotton yields in the northern provinces can be expected to incrcase, as a rosult of improved cultivation practices alone, by an amount in the order of magnitude of 10 seers of seed cotton per jirib** (350 kg/ha), resprosenting about a 25 per cont incroase over average curront yields in these aroas. These improved results can be realized by the introduction of rowcropping and appropriate inter-cultivation with animal-drawn implements and hand tools. Inter-cultivation is a prerequisite for the efficient application of fortilizors. It is strongly recommended that horses of the northorn provinees be used for the light cultivation work in rowerops.

2. An investment of $\$ 100.00$ in new cultivation equipment would suffice for the propor cultivation of 30 jiribs ( 6 ha) during one season. (See point 7 below). The following results may then be realized:-

Increase of yield on 30 jiribs - 300 seers seedcotton or - $2100 \mathrm{~kg}$ scedcotton equal to

- $700 \mathrm{~kg}$ cotton lint

Afghan ootton at present realizes US $\$ 0.75$ por $k_{g}$ on the world market.

$700 \mathrm{~kg}$ cotton at a price of US $\$ 0.75$ por $\mathrm{kg}=$ US $\$ 525.00$.

In other words, the investments in this program can be reprom duced fivo times in the first year. The equipment should last from 5 to 15 years oven under the difficult Afghan conditions. Thus funds will become available at a fast growing rate; which should be re-invested in a quickly cxpanding program. The above calculation is basod on estimates. It loaves ample space for variations in the initial investment, yield per jirib, and price of lint. What matters is the ratio between investment and production which is sufficiently sound and favourable to be used as a base for the program.

3. At prosent the acreage under cotton in northern Afghanistan is approximately 60,000 ha. It is proposed to establish rowcropping with animal-drawn implements throughout the area in six years, starting with an initial investment for the first year of US $\$ 20,000.00$ and financing subsequent expansion from the annual roturns in accordance with the following plan:-

* 1 seer equals $7 \mathrm{~kg}$ (kilogram)

** 1 jirib equals 0.2 ha (heotare)

FAO $/ 58 / 4 / 2445$ 


\section{Investment}

\begin{tabular}{|c|c|c|c|c|c|}
\hline \multicolumn{5}{|c|}{ Investment } & \multirow[b]{2}{*}{$\begin{array}{c}\text { Value of } \\
\text { increased } \\
\text { production }\end{array}$} \\
\hline Year & $\begin{array}{l}\text { Sets of } \\
\text { equipment }\end{array}$ & US 限 & $\begin{array}{l}\text { Cultivated } \\
\text { area in Ha }\end{array}$ & $\begin{array}{l}\text { Increase in lint } \\
\text { production in } \mathrm{kg}\end{array}$ & \\
\hline First & 200 & 20,000 & 1,200 & 140,000 & $\begin{array}{c}\text { US } \$ \$ \\
105,000\end{array}$ \\
\hline Second & 400 & 40,000 & 3,600 & 420,000 & 315,000 \\
\hline Third & 600 & 60,000 & 7,200 & 840,000 & 630,000 \\
\hline Fourth & 1,200 & 120,000 & 14,400 & $1,680,000$ & $1,260,000$ \\
\hline Fifth & 2,400 & 240,000 & 28,000 & $3,360,000$ & $2,520,000$ \\
\hline Sixth & 4,800 & 480,000 & 57.600 & $6,720,000$ & $5,040,000$ \\
\hline Total & 9,600 & 260,000 & 57,600 & $13,160,000$ & $2.870,000$ \\
\hline
\end{tabular}

4. It is estimated that the purchased equipment will have an average lifetime of 10 years. In this period, each set costing US $\$ 100.00$ should reproduce $7,000 \mathrm{~kg}$ lint in excess of the former yield. 10,000 sets representing an investment of US $\$ 1,000,000$ should reproduce $70,000,000 \mathrm{~kg}$ cotton lint in ten years.

At the price of $\$ 0.75$ per $\mathrm{kg}$ the resulting gross return would amount to US $\$ 52,500,000$.

5. The full success of such a program is dependent on the efficient cooperation of the following individuals and institutions:-

The Ministry of Agriculture supervising and financing the program together with its appropriate Departments and

Services.

A responsible leader of the program.

The Bank of Agriculture and Cottage Industries.

Provincial and Local Governments.

The Cotton Comnany and the Cotton Cooperative.

Press and Radio. 
International and bilateral agencies extending technical assistance to Afghanistari.

Individual cultivators and landlords.

Village leaders.

Farming Societies or cooperatives created to facilitate the operation of the program.

Local tradesmen who must be incorporated for repairs and spare parts.

6. The plan would start with amodest 200 sets of equipment in the first year, totaling 1,200 sets in tho third yoor. This time allowance is given to enable all concerned to understand the program and then to build up the services and organizations required for expansion in the following years. The program of the first year is adapted to the present number of Government officers in the cotton area. Each of the 10 men ( 8 Kataghan, 2 Mazar-i-Sharif) to each of whom 3 or 4 assistants should be assigned, would introduce the new methods and the equipment to 20 progressive farmers in the first year. The assistants would be trained in service during the first year and then be appointed as advisers in the second year. 60 - 80 assistants would be trained in the second year to function as advisers in the third year, and so on through the following years. It is not possible for the Ministry of Agriculture to recruit such personnel from their normal sources. Local people would have to be hired but the Ministry would have to provide the higher grade staff. Staff requirements for the later years will become evident after the first year's experience.

7. A set of cultivation implements consists basically of the following:-

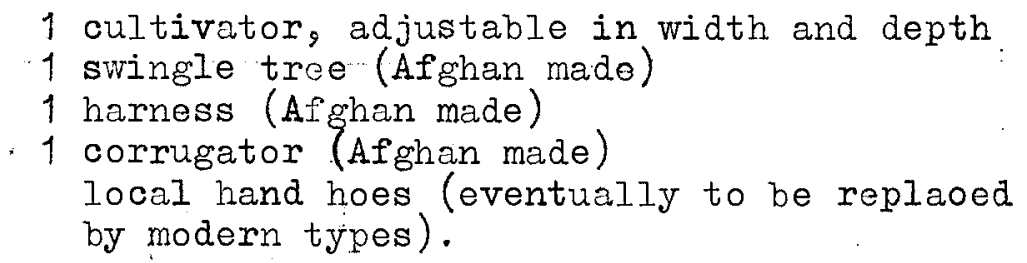

This set will suffice for the areas where cotton is grown on the flat. For areas where cotton is grown on ridges, the corrugator is replaced by a furrower or ridger. The common. horse hoe, called also adjustable cultivator, made by a large number of manufacturers in Europe and in the United States of America, with exchangeable sweeps and ridging bodies, is recommended for cultivation purposes. When exchanging the 
different tools on the frame, the farmers obtain their first experience with nuts and bolts and wrenches. They will acquire some basic mechanical skill which is very important for any future mechanization project. The implement has given satisfactory results with all working parts in Afghanistan. year:

Suggested distribution of implements during the first

Combined

cultivator-

Centres ridgors:

Ridgers Cultivators Corrugators Harness

Swingle

Troes

\begin{tabular}{lcccccc} 
Baghlan & 4 & 12 & 16 & 8 & 20 & 20 \\
Kundus & 6 & - & 34 & 40 & 40 & 40 \\
Khanabad & 3 & - & 17 & 20 & 20 & 20 \\
Taloquan & 4 & 12 & 16 & 8 & 20 & 20 \\
Khoja-Ghar & 4 & 16 & 16 & 20 & 20 & 20 \\
Iman Sahib & 3 & 7 & 17 & 20 & 20 & 20 \\
Kala Hizal & 3 & 7 & 17 & 20 & 20 & 20 \\
Mazar-i-Sharif & 6 & - & 34 & 40 & 40 & 40 \\
\hline Plus 20\% Reserve & 7 & 11 & 33 & 34 & 40 & 40 \\
\hline Total & 40 & 65 & 200 & 210 & 240 & 240 \\
\hline
\end{tabular}

8. Samples of Indian cultivation equipment have been ordered by FAO and have been shipped to Afghanistan. This equipment can be hooked with the beam to the double yoke. If the tests prove satisfactory, it should be included in the program.

9. Due consideration must be given to the length of time requirod for foreign equipment to arrive in Afghanistan. Tho equipment for the first two years should be ordered at once, and the orders for the later years should be placed well ahead of schedule. 
Equipment presently stored by the Ministry of Agriculture in. different areas of the country should be used for demonstrations to the farmers. Only new equipment should be distributed to the farmers.

10. The senior staff would have to be provided with jeep transport and the local field officers with saddle horses, which could also be used in light draft for demonstrations in intercultivation. Decisions in each case should be taken on the advice of the project leader.

11. A project leader should be appointed. One of his first duties would be to work out the budget. The requirements of this progrom will be high, and therefore it is recommended that as much encouragement as possible, through salaries, allowances, prizes, etc., should be given.

Timely Operation. In the course of the progressing program, primary attention must be given to factors affecting the timely performance of the field work. Care must be taken that the fields are ploughed in avance and are ready for timely sowing or planting. Cotton planting with simple seeders can be introduced when delinted seed becomes available. Cultivation and particularly inter-cultivation must be done when the soil is in a. suitable condition and the weeds small and weak. The promotion of the scythe and cradle will release manpower for the inter-cultivation of the rowcrops. Further tests with disc or roller threshers on the one hand, and drum threshers on the other, must be carried out and an early decision taken as to which method will be adopted in order to release animal power and labour for the uninterrupted cultivation of rowcrops throughout the harvesting season:

FAO Report No. 195 recommended that the abundant spring grass in the Steppes of northern Afghanistan be used for hay. With the scythe and the horse-drawn mower, implements are at hond wich ollow the storago of winter fodder to prevent losses from starvation in the national sheep industry. It is recommended that besides the program in cotton, a project for the conservation of winter fodder be initiated as soon as the Ministry can make personnel available.

Establishment of an Agricultural Engineering Section within the Ministry of Agriculture

For the success of the program the Government should assume certain services, some of which may only be on a temporary basis. In effect, the Government should provide facilities for: 
1. ordering adequate numbers of implements and spare parts,

2. payment of accounts with foreign companies,

3. distribution of implements to farmers,

4. adequate credit for farmers to purchase the implements,

5. means of instructing farmers in the care, use and maintenance of the implements.

This will involve:

(a) The establishment of an Agricultural Engineering Section within the Ministry of Agriculture. A qualified officer of the Ministry should be made responsible for the development of this section and appointed as chief for all questions of egricultural engineering. This officer should have adequate responsibility and authority to carry out this task and should be required to attend regular meetings of the Technical Board of the Ministry.

(b) In order to maintain continuity of the responsibilities and working of the section a deputy chief should be appointed. The deputy should have responsibility for training field officers and some other permanent activities of the Section and should, on all occasions when the chief is absent have full authority to act in his stead.

(c) Provision should be made for the expansion of facilities for the purchase, storage and distribution of farm implements. It is considered advisable for the Ministry to establish, on a temporary basis, its own Depot of Supplies, which would have responsibility for the purchase and the distribution of equipment needed for Ministry projects. This Depot should. extend its relations to private farm equipment enterprises. Once the whole development has entered an advanced stage the Depot could hand over its rosponsibilitios to private enterprise.

(d) The development of a credit scheme in cooperation with the Bank of Agriculture and Cottage Industries.

(e) The expansion of training activitios to moot requirements in the project areas.

(f) The eventual provision for testing of farm implements and the training of Govornment officers and farm leadors in their use and maintenance.

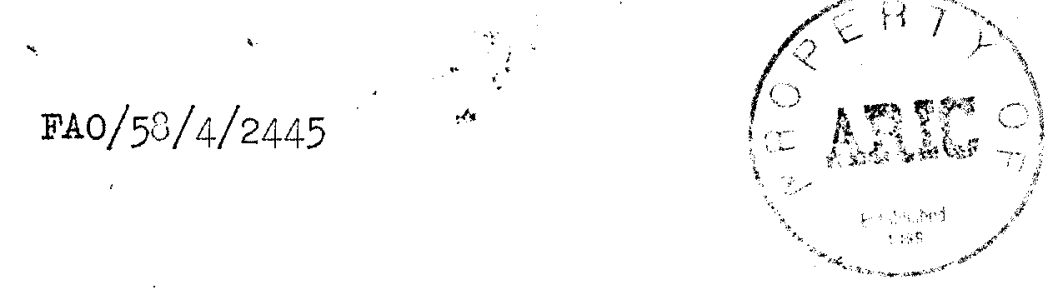

